[6]. Ofitsiinyi sait firmy «HUM». URL: http://hum.com.tr/teknolojiler-ru_3/kstraktsiya/

[7]. Khobin V.A. Konspekt lektsii z kursu «Identyfikatsiia ta modeliuvannia tekhnolohichnykh ob `iektiv» dlia studentiv, yaki navchaiutsia za spetsialnistiu 151 «Avtomatyzatsiia ta komp iuterno-intehrovani tekhnolohii» dennoi ta zaochnoi formy navchannia.- Odesa: ONAKhT, 2016 - 96s.

[8]. Khobin V.A. Konspekt lektsii z kursu «Teoriia avtomatychnoho keruvannia» dlia studentiv, yaki navchaiutsia za spetsialnistiu 151«Avtomatyzatsiia ta komp iuterno-intehrovani tekhnolohii» dennoi ta zaochnoi formy navchannia.Odesa: ONAKhT, 2012.-Ch.1-112s.

[9]. Khobin V.A. Konspekt lektsii z kursu «Teoriia avtomatychnoho keruvannia» dlia studentiv, yaki navchaiutsia za spetsialnistiu 151 «Avtomatyzatsiia ta komp iuterno-intehrovani tekhnolohii» dennoi ta zaochnoi formy navchannia.Odesa: ONAKhT, 2019.-Ch.2-72s.

[10]. Khobin V.A. Sistemy garantiruyuschego upravleniya tekhnologicheskimi agregatami: osnovy teorii, praktika primeneniya. / Odesskaya nacional'naya akademiya pischevykh tekhnologii - Odessa: «TES», 2008. - 306 s.

УДК 004.896:621.798.1-033.5:66.013(477.74)

\title{
АВТОМАТИЗАЦІЯ БІЗНЕС-ПРОЦЕСУ ВИРОБНИЦТВА СКЛЯНОЇ ТАРИ
}

\author{
Аскаров Н. А. \\ Одеська національна академія харчових технологій \\ ORCID: https://orcid.org/0000-0003-2358-868X \\ E-mail: askarovnurlan777@gmail.com
}

Copyright (C 2021 by author and the journal “Automation of technological and business - processes”. This work is licensed under the Creative Commons Attribution International License (CC BY). http://creativecommons.org/licanses/by/4.0
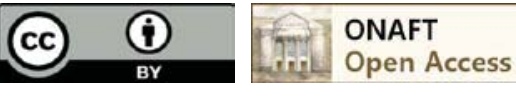

DOI:

Анотація. Для ефективної роботи підприємства необхідно високоефективне управління, яке в сучасних умовах спирається на певні програмні продукти. Питання розробки сучасних програмних продуктів є актуальним, багато розробників запропонували свої рішення.Загальним недоліком всіх рішень є низька гнучкість систем, - для їх адаптаціі під конкретне підприємство потрібна робота кваліфікованого програміста. На кафедрі автоматизації виробничих процесів та робототехнічних систем ОНАХТ в рамках дипломної роботи бакалавра було розроблено систему управління бізнес-прочесом виробництва скляної тари на підприємстві Ілона ЛТД. Створено модель організаційної структури підприємства, яка відображає розподіл роботи по підрозділах $і$ управлінським органам, між якими формуються певні відносини, пов'язані з реалізацією владних повноважень, потоків розпоряджень та інформації. Проведене виділення бізнес-процесів підприємства та створення його процесної моделі, яка описує процес послідовного перетворення матеріальних, сировинних і інформаційних потоків підприємства дозволило визначити процеси для подальшої їх автоматизації. Розроблена ВМРN нотація, яка відображує в зручной формі бізнес-процеси, які проходять в компанї, та їх зв'язок, послідовність, відношення до структурних підрозділів дозволила остаточно визначити конкретні прочеси для автоматизачії. Розроблене та затверджене технічне завдання на створення програмного забезпечення для АСУП, а саме створення програмного продукту зберігання, контролю, обліку $і$ аналізу даних про замовлення, складськи запаси сировини, готової продукціi, постачальників та замовників, результатів інвентарізаиї, розрахунків сировини для виробництва стало основою для розробки програмного продукту - сайту. Створення інтерфейсів та функиіоналу для кожного з керівників бізнес-процессів, яки були автоматизовані забезпечило зручне використання програмного продукту для користувача. Подальший розвиток питання автоматизаиії управління процесом виробництва скляної тари знайде в випускній роботі магістра.

Abstract. For effective operation of the enterprise it is necessary highly effective management, which in modern conditions relies on certain software products. The issue of developing modern software products is relevant, many developers have proposed their decisions. The general disadvantage of all decisions is low flexibility of systems, - for their adaptation, a qualified programmer is needed for their adaptation. At the Department of Automation of Production Processes and Robotic Systems of OANT in the framework of the bachelor's diploma work, a business process management system was developed at the production of a glass container at the Ilona Ltd. The model of the organizational structure of the enterprise is created, which reflects the distribution of work on subdivisions and management bodies, between which certain relations are formed 
associated with the implementation of power powers, streams of orders and information. The allocation of business processes of the enterprise and the creation of its process model, which describes the process of successive transformation of material, raw material and information flows of the enterprise allowed to identify processes for further automation. The BMPN notation has been developed, which reflects in a convenient form of business processes that take place in the company, and their connection, consistency, relation to structural subdivisions allowed to finally determine specific processes for automation. The developed and approved technical task for the creation of software for ASUP, namely the creation of a software product of storage, control, accounting and analysis of order data, warehouse stocks of raw materials, finished products, suppliers and customers, inventory results, raw materials calculations for production became the basis for developing software product site. Creating interfaces and functionality for each of the business process managers, which were automated provided userfriendly use of the user. Further development of the automation of the management of the production of glass containers will find in the master's degree.

Ключові слова: бізнес-процес, автоматизація управління підприємством, виробництво скляної тари, програмний продукт, автоматизована система управління підприємством (АСУП), Aris Express.

Keywords: business process, enterprise management automation, production of glass containers, software product, automated enterprise management (control) system (AEMS), Aris Express.

Вступ. Бізнес-процеси є невід'ємною складовою життєвого циклу будь-якої організації і можна сказати, що в цілому, що усе, що відбувається в організації описується набором таких процесів. Як відомо процес - стійка, цілеспрямована сукупність взаємозв'язаних видів діяльності, яка за певною технологією перетворить входи у виходи, представляюча цінність для споживача (клієнта). Оскільки в епоху капіталізму ефективність компанії може бути виміряна розміром прибутку, який вона приносить, максимізація отримуваного прибутку є однією 3 основних цілей, як підприємця, так і будь-якої організації в цілому. Як відомо, у будь-якій компанії кількість людського ресурсу обмежена і тому, обмежений можливий об'єм виконуваної ним роботи. Виходячи з цього, автоматизація частини роботи, вироблюваної співробітниками, звільняє частину виробничого часу компанії, дозволяючи вкласти його в інші завдання, виконання яких, приведе до подальшого збільшення економічної ефективності.

Аналіз літературних даних i постановка проблеми. Для ефективної роботи підприємства необхідно високоефективне управління, яке в сучасних умовах спирається на певні програмні продукти. Оскільки це питання $є$ актуальним, багато розробників запропонували свої рішення.

Корпорація Oracle в 2012 году представила облачну систему управління Oracle Cloud ERP[1]. Cистема керує функціями підприємства, включаючи бухгалтерський облік, фінансове управління, управління проєктами та закупками.

Даний продукт має наступні недоліки: довгий час внедріння системи, низька гибкість системи, неможливість значних модифікацій

Компанія 1С пропонує свій продукт 1С:Підприємство[2] - програмний продукт, призначений для автоматизації діяльності підприємства.

Недоліками даного програмного продукту є потрібність платити за оновлювання продукту, та необхідність настроювання системи під потреби конкретного підприємства, яке виконується лише за допомогою кваліфікованих спеціаліствів.

BAS ERP[3] - ERP система від «1C Первый Бит» для України. Призначена для автоматизації великих підприємств зі складними технологічними процесами, позиціонується як система здатна забезпечити потреби будь-яких масштабів починаючи від 50 робочих місць.

Компанія «СофтПро» пропонує свій продукт Универсал[4]- багаторівневе рішення класу ЕRP для автоматизації бізнес-процесів середнього та великого бізнесу. Забезпечує комплексну автоматизацію різних бізнес-процесів, робить їх прозорими і легко керованими. $\mathrm{C}$ Web-версія для доступу через інтернет.

Загальним недоліком всіх перерахованих рішень $є$ низька гнучкість систем, для їх адаптації під конкретне підприємство потрібна робота кваліфікованого програміста.

На кафедрі автоматизації виробничих процесів та робототехнічних систем ОНАХТ в рамках випускної роботи бакалавра було розроблено систему управління бізнес-процесом виробництва скляної тари на підприємстві Ілона ЛТД[5]. Система призначена конкретно для цього підприємства, є зручною в налаштуванні та відкритою для додавання нових функцій.

Мета і завдання дослідження. Метою дослідження є поглиблення уявлень про бізнес-процеси в сфері управління виробництвом скляної тари. Завданнями дослідження $є$ автоматизація бізнес-процесів інвентаризації, прийому заявок від клієнтів, розрахунку потреб в сировині для виробництва.

Методи і матеріали досліджень. Основним використаним методом є діалектичний. Також використано такі методи: аналіз, синтез, індукція, дедукція, спостереження. Основним експериментальним методом обрано імітаційне моделювання.

Результати досліджень. Першим кроком розробки було створення за допомогою програмного інструменту ARIS Express моделі організаційної структури підприємства (рис.1), яка відображує розподіл роботи по підрозділах і управлінським органам, між якими формуються певні відносини, пов'язані з реалізацією владних повноважень, потоків розпоряджень та інформації. 


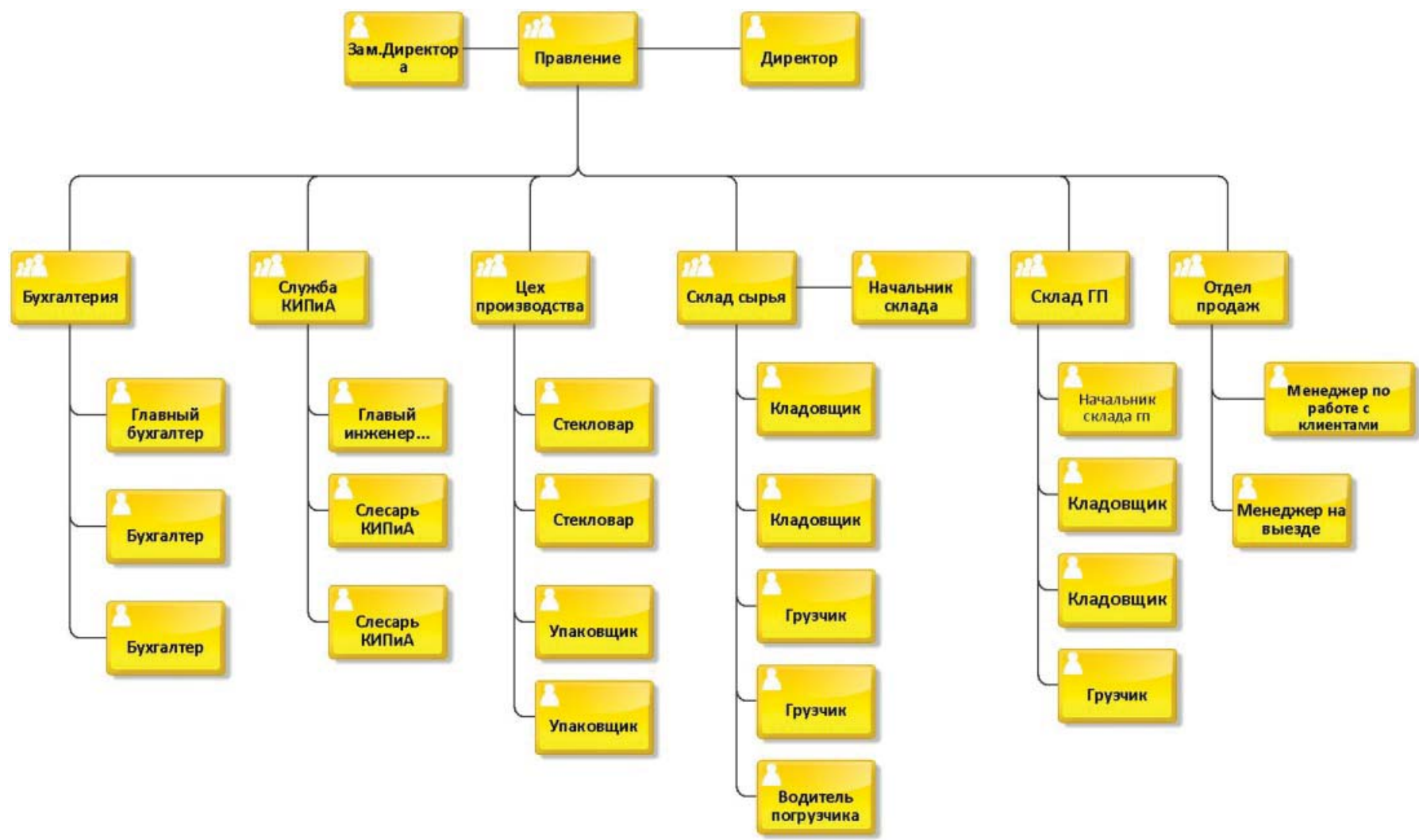

Рис. 1. - Модель організаційної структури підприємства « Ілона ЛТД»

Далі було проведене виділення бізнес-процесів підприємства та створення його процесної моделі, яка описує процес послідовного перетворення матеріальних, сировинних і інформаційних потоків підприємства.

Процесна модель може бути отримана за допомогою нотації Process landscape програмного інструменту Aris Express (рис. 2).

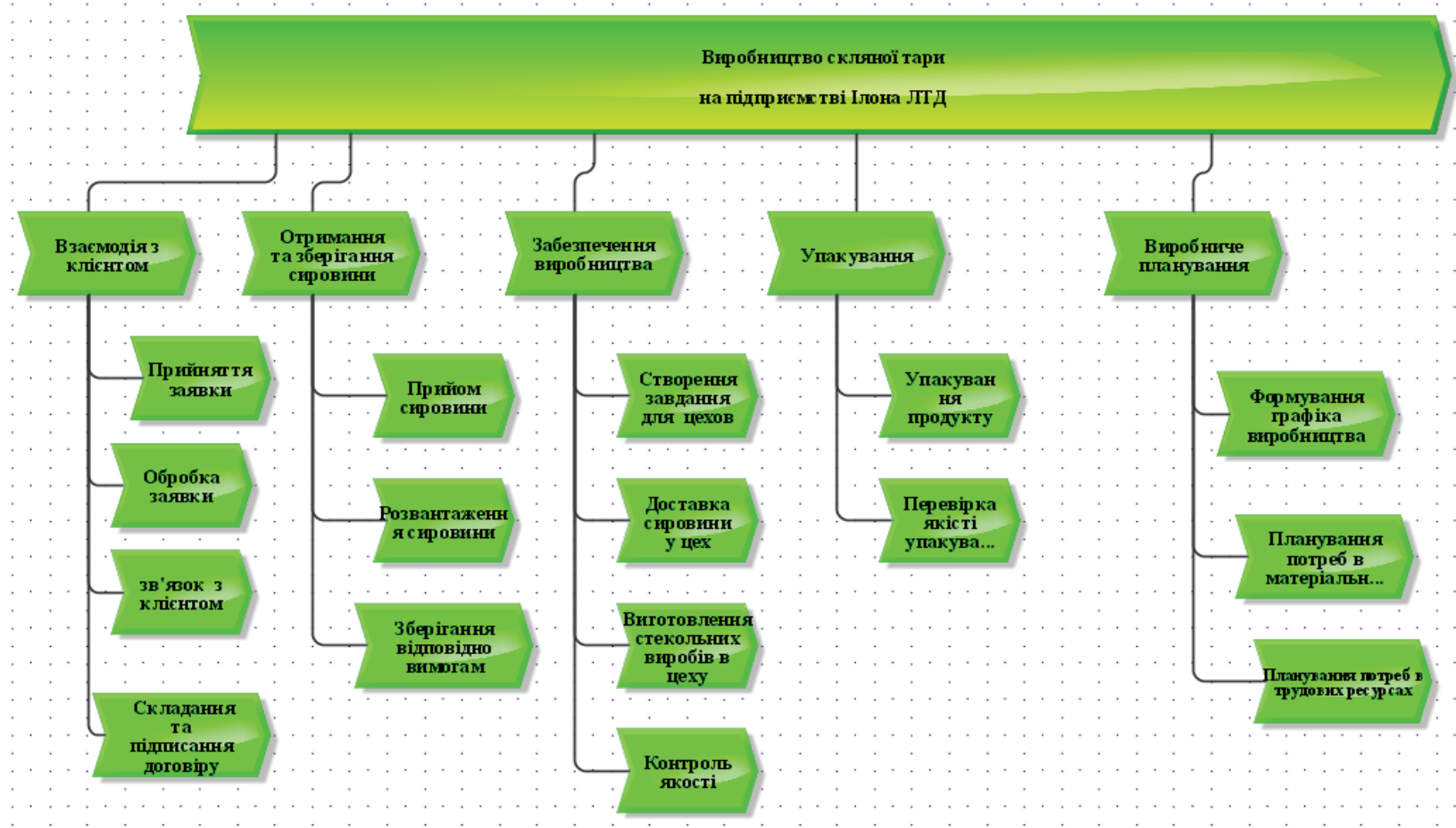

Рис. 2 - Модель процесної структури підприсмства «Ілона ЛТД» 
Наступним етапом була розробка BMPN нотації, яка відображує в зручній формі бізнес-процеси, які проходять в компанії, та їх зв'язок, послідовність, відношення до структурних підрозділів. Були виділені процеси, які можливо автоматизувати. Створена в нотації BPMN модель бізнес-процесу «Виготовлення на замовлення» наведена на рисунку 3.

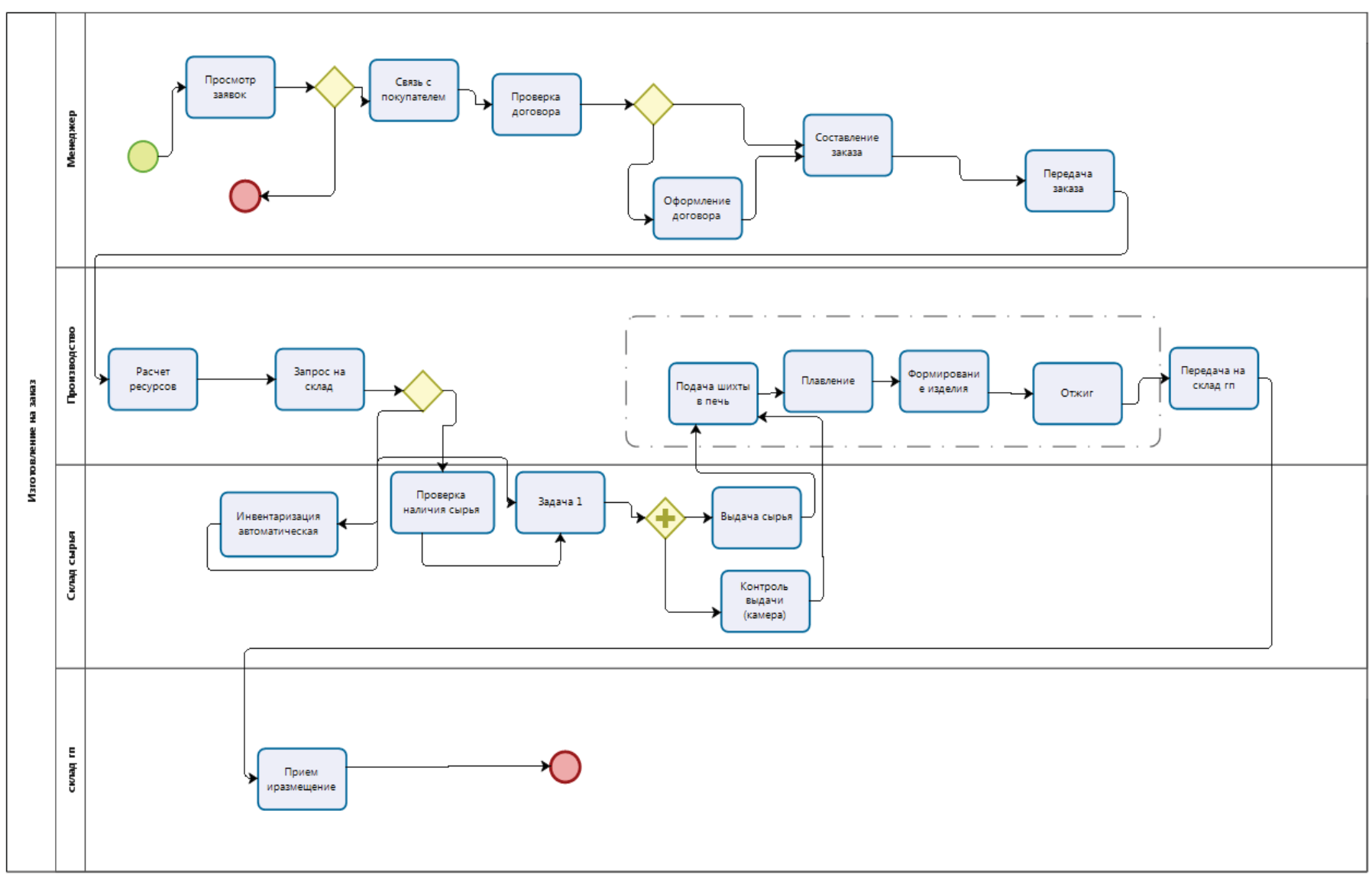

\section{Рис. 3 - Модель бізнес-процесу, створена в нотації ВPMN}

Визначені завдання кожного учасника, а так само його взаємозв'язок з іншими учасниками даного бізнес-процесу:

Менеджер з продажу: його задача прийняти заявку,обробити, зв'язатися з клієнтом для обговорення умов угоди та підписання договору; скласти замовлення на виробництво.

Виробництво: задача планування потреб у сировинних ресурсах та запиту на склад їх наявності, а також безпосередньо у виробництві.

Склад сировини: його головна задача - перевірка наявності необхідної для виконання замовлення сировини і передача сировини на виробництво.

Склад готової продукції: прийом і разміщення ГП

В обраній моделі були виділені наступні задачи, які будуть реалізовані у веб-додатку:

Інвентаризація-буде автоматизована за допомогою сканеру штрих-кодів та програми для звязку 3 ним, ця функція буде у інтерфейсі начальнику складу.

Розрухунок-буде автоматизована за допомогою створення калькулятору сировини, ця функція буде у інтерфейсі начальнику виробництва.

Контроль выдачи- буде автоматизован за допомогою веб-камери та програми для звязку з нею,ця функція буде у інтерфейсі начальнику складу

Прийом заявок- буде відбуватися через веб-сайт, ця функція буде у інтерфейсі менеджеру з продажу.

Було розроблено та затверджено технічне завдання на створення програмного забезпечення для АСУП, а саме створення програмного продукту зберігання, контролю, обліку і аналізу даних про замовлення, складськи запаси сировини, готової продукціі, постачальників та замовників, результатів інвентарізації, розрахунків сировини для виробництва.

При проектуванні бази даних було розроблено концептуальну модель даних за методологію Data model в ARIS EXPRESS. Концептуальна модель даних відображує таблиці бази даних, їх поля та зв’язок між таблицями (рис.4). На основі моделі було створено базу даних. 


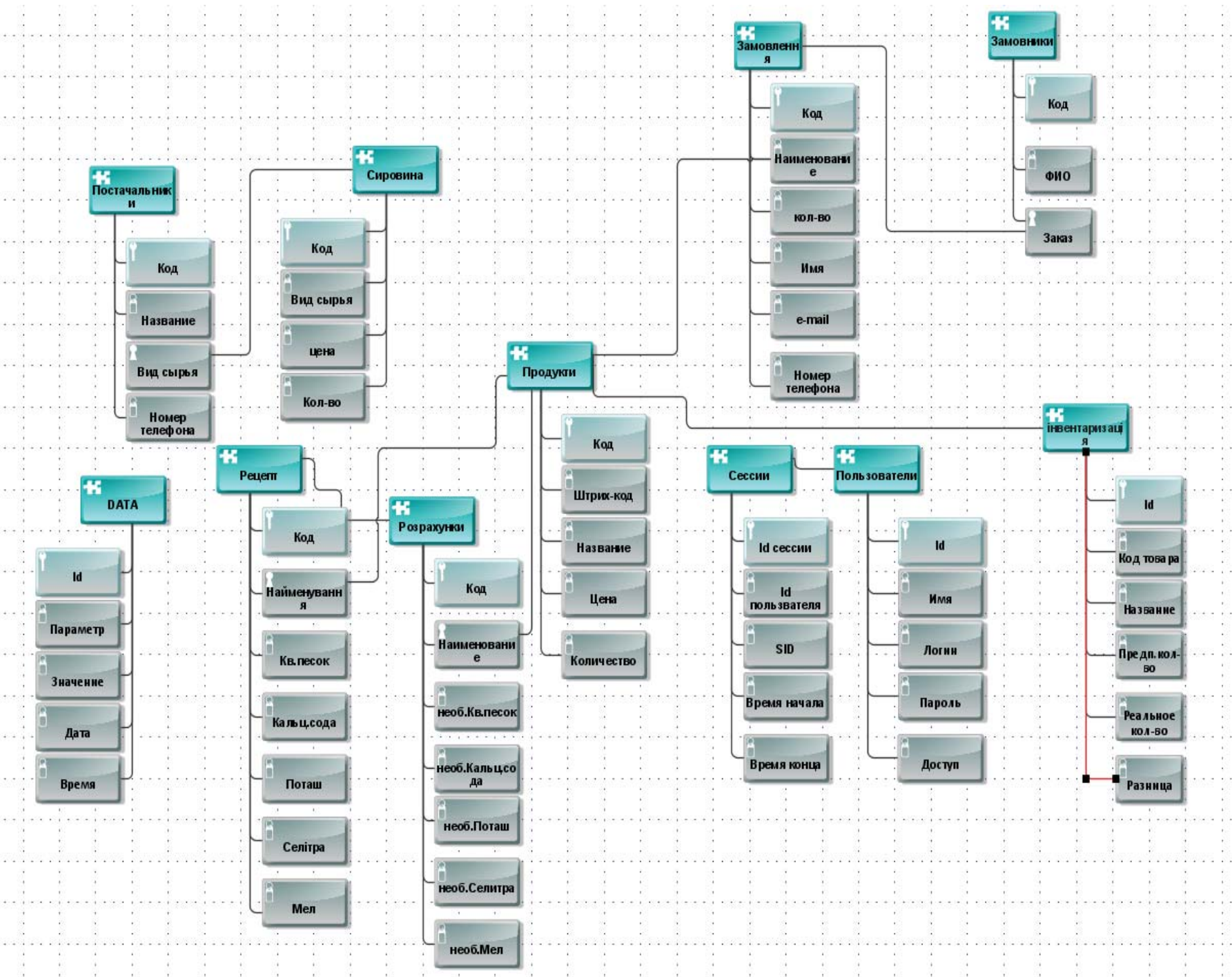

Рис.4 - Модель даних

Наступним етапом стало створення інтерфейсів та функціоналу для кожного 3 керівників бізнес-процессів, яки були автоматизовані. Кожний з користувачів системи має свій інтерфейс та функціi, яки доступні для його посади. Спочатку було створено вікно для авторизації користувача (рис.5).

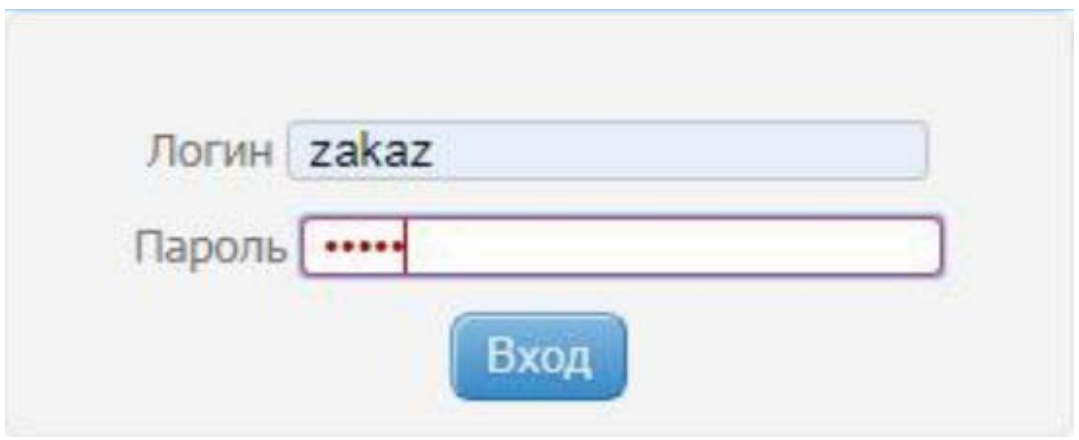

\section{Рис.5 - Вікно авторизації користувача}

Процес прийняття заявки від клієнта був автоматизован за рахунок додавання на сайт каталогу, через який клієнт може залишити заяву на замовлення, вказав свій номер телефону, потребну кількість продукцііі, імя. Після того, як клієнт залишить заявку, менеджер з продажу зможе її побачити в вкладці «Заказы» (рис.6). 


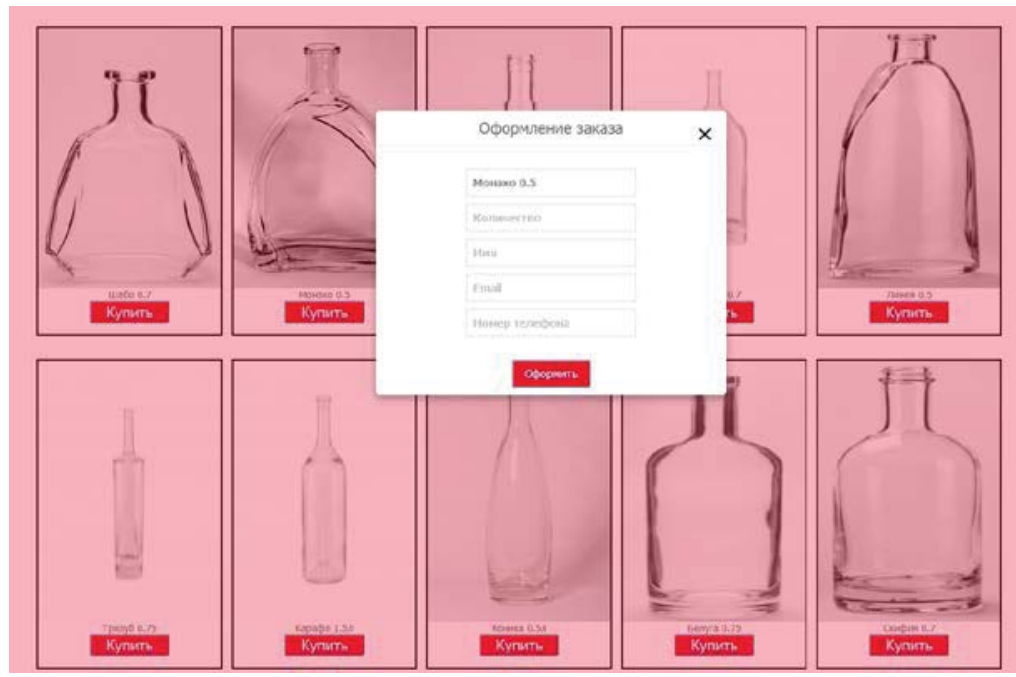

Рис.6 - Оформлення заяви покупцєм на сайті

Для менеджеру з продажу створен свій інтерфейс, в якому він має можливість оглянути заяви від клиєнтів, перевірити наявність на складі необхідних клієнту товарів (рис.7).

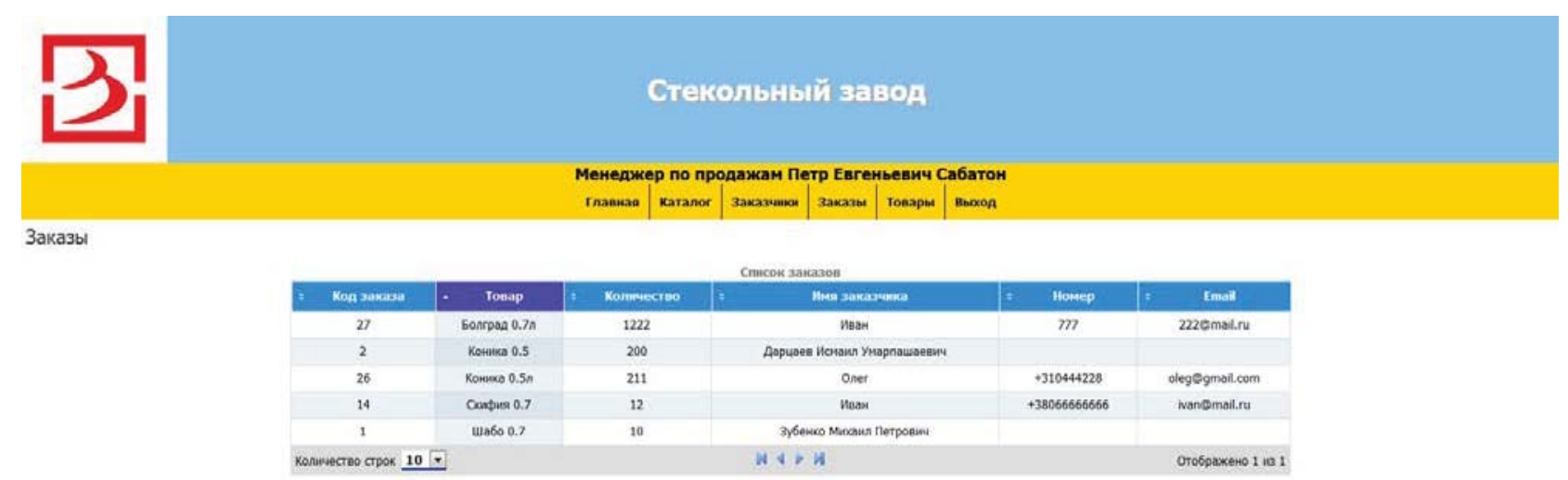

\section{Рис. 7 - Вікно перегляду заяв від кліснтів}

Для начальника виробництва була створена можливість за допомогою функції «Расчет сырья» розрахувати витрати всіх видів сировини на виробництво певної кількісті продукції (рис.8 ). Також начальник виробництва має можливість стежити за температурою в основному технологічному апараті - скловарній печі (рис.9).

\begin{tabular}{|c|c|c|c|}
\hline Главная & Каталог & График & Расчет сырья \\
\hline & & \multicolumn{2}{|c|}{ Введите название } \\
\hline & & \multicolumn{2}{|c|}{ Болград 0.7л } \\
\hline & & \multicolumn{2}{|c|}{ Введите количество } \\
\hline & & \multicolumn{2}{|c|}{3111} \\
\hline & & \multicolumn{2}{|c|}{$\begin{array}{l}\text { Необходимое кол-во, кг } \\
\text { Кв.песок }\end{array}$} \\
\hline & & \multicolumn{2}{|c|}{650.199} \\
\hline & & \multicolumn{2}{|c|}{$\begin{array}{l}\text { Кальцинированная сода } \\
149328\end{array}$} \\
\hline & & & Поташ \\
\hline & & \multicolumn{2}{|c|}{108.885} \\
\hline & & \multicolumn{2}{|c|}{ Селитра } \\
\hline & & \multicolumn{2}{|c|}{35.7765} \\
\hline & & \multicolumn{2}{|c|}{ Мел } \\
\hline & & \multicolumn{2}{|c|}{115.107} \\
\hline & & & Отправить \\
\hline
\end{tabular}

Рис.8 - Розрахунок потреб в сировині 

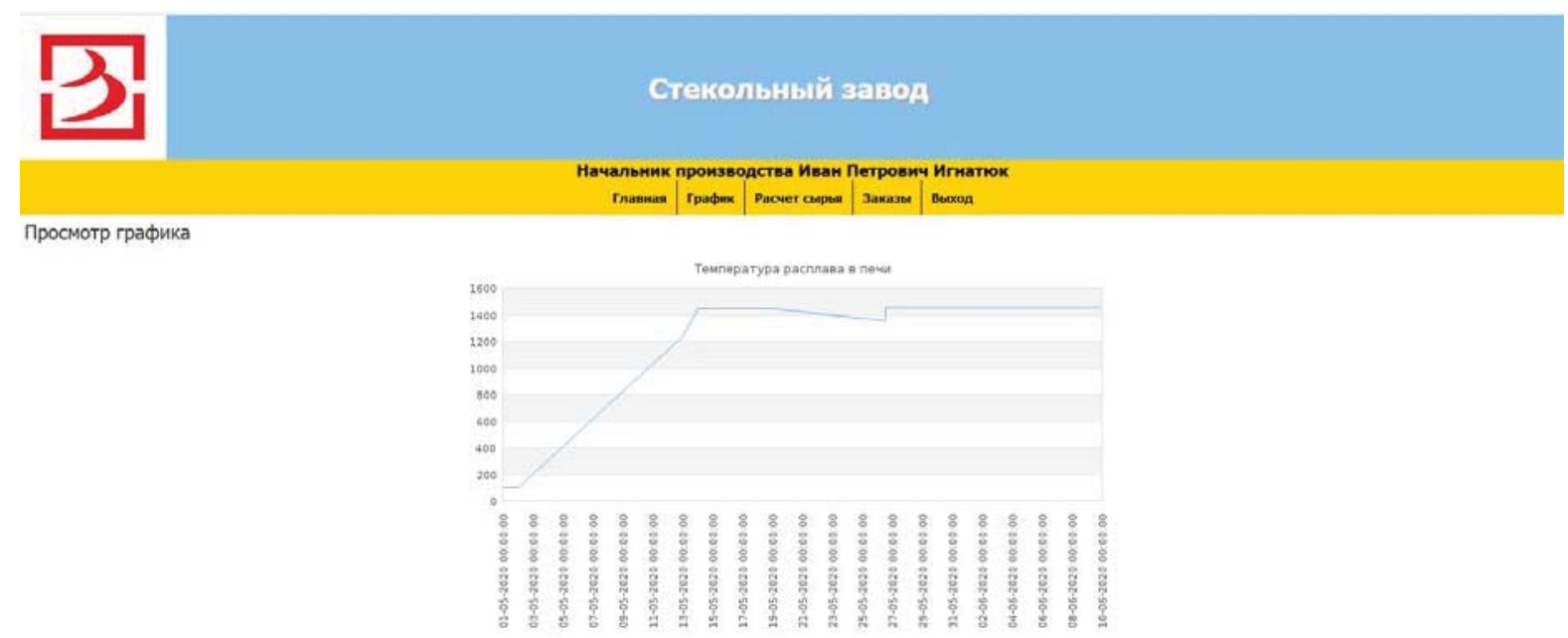

Рис.9 - Графік температури в скловарної печі

Інтерфейс начальника складу сировини відрізняється можливістю моніторингу запасів на складі (рис.10), та відеоспостереження за складом.

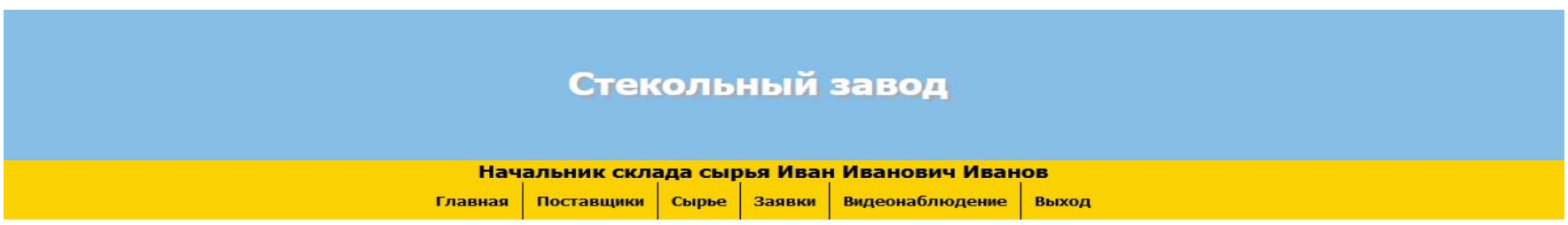

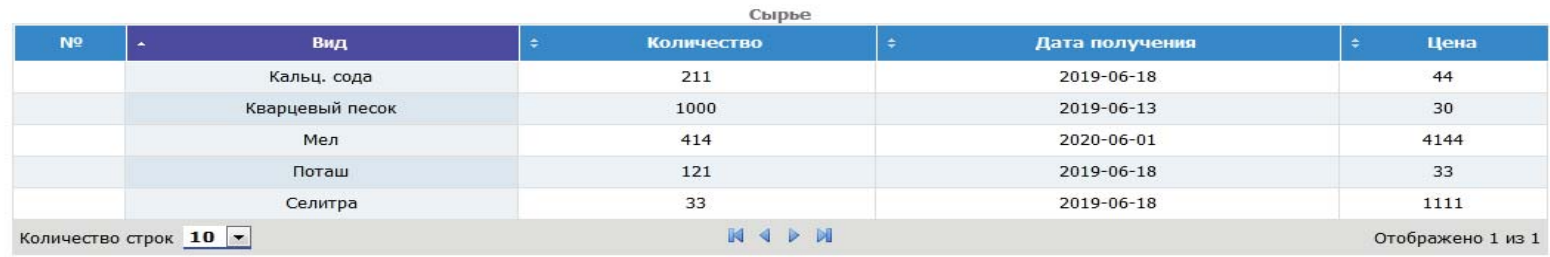

\section{Рис.10 - Сторінка моніторингу запасів сировини на складі}

Начальник складу сировини отримає замовлення на видачу сировини від виробництва, які може переглянути на сторінці «Заявки» (рис.11).

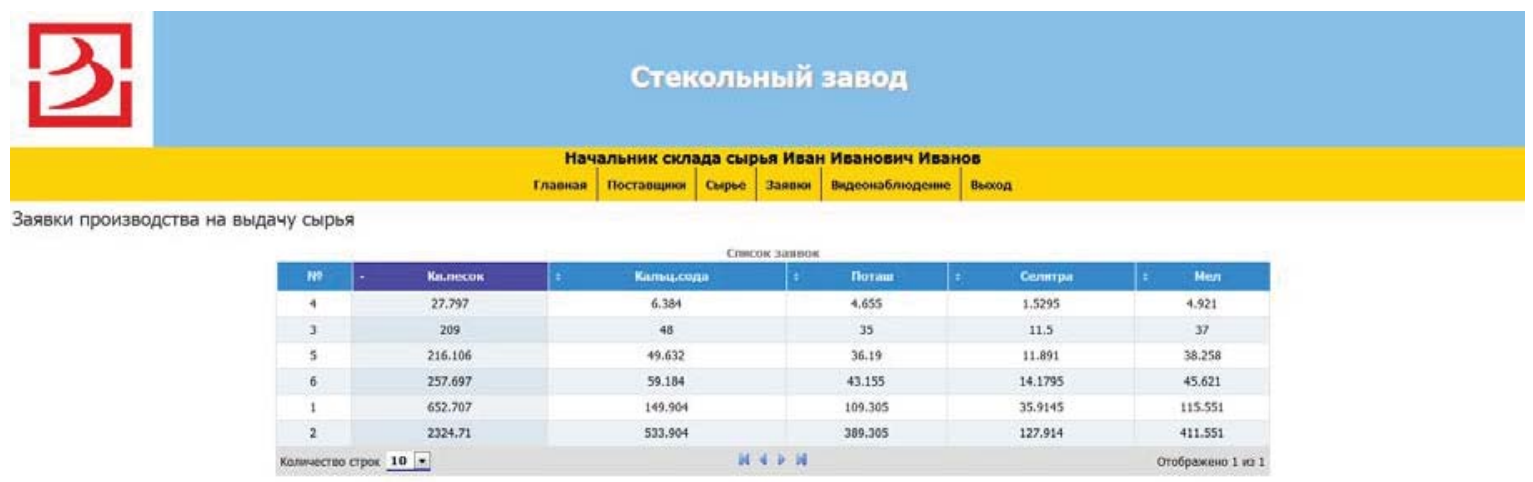

Рис.11 - Сторінка «Заявки» інтерфейсу начальника складу сировини

Для начальника складу готової продукції (ГП) передбачена функція інвентаризації на складі за допомогою сканеру штрих-кодів (рис.12). Програма автоматично розраховує різницю між очікуваною та реальною кількістю товарів та показує різницю в грошовому еквіваленті. 


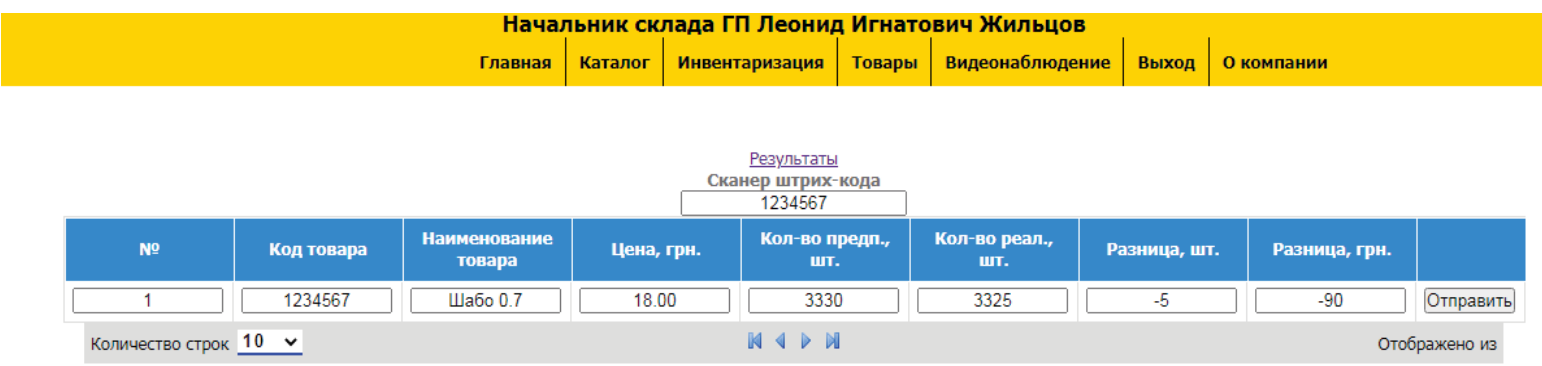

Рис.12 - Сторінка інвентарізації інтерфейсу начальника складу готової продукції

Також для начальнику складу ГП реалізована можливість спостерігати за роботою на складі: в його інтерфейсі передбачена сторінка перегляду зображення з відеокамер, встановлених на складі готової продукції (рис. 13).
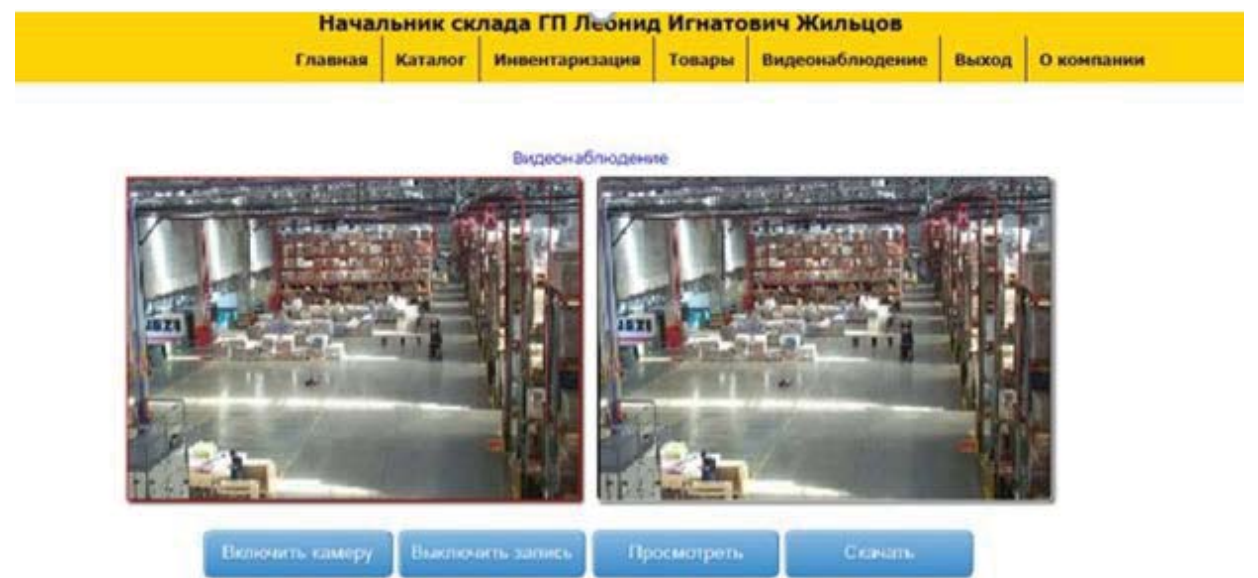

Рис. 13 - Сторінка перегляду відеокамер інтерфейсу начальника складу готової продукції

\section{Обговорення результатів дослідження.}

Розроблено комплекс моделей бізнес-процесів підприємства. Створенно імітаційну модель процесу управління виробництва скла. Розроблено технічне завдання на створення нового веб-додатку, як основи АСУП. Розробленно та створено концептуальну модель даних та структури бази даних. Розроблені макети для інтерфейсів користувачів та їх дизайну, верстка дизайн-макетів. Створення функціональних модулів. Ствоерно SCADA-систему для технологічного об'єкту моніторингу і(або) управління, забезпеченя іiі зв’язок із створеним веб-додатком. Обрано технічні засобі, мета використання і реалізація їх зв'язку із створеним веб-додатком. Обрано методі інтелектуального аналізу даних, представлення результатів їх застосування, розробка алгоритмів для автоматизації підтримки прийняття рішень. Обгрунтувано економічну доцільність впровадження роботи.

\section{Висновки}

1.Для ефективної роботи підприємства необхідно високоефективне управління, яке в сучасних умовах спирається на певні програмні продукти.

2. Питання розробки сучасних програмних продуктів $є$ актуальним, багато розробників запропонували свої рішення.Загальним недоліком всіх рішень $є$ низька гнучкість систем, - для їх адаптації під конкретне підприємство потрібна робота кваліфікованого програміста.

3. На кафедрі автоматизації виробничих процесів та робототехнічних систем ОНАХТ в рамках дипломної роботи бакалавра було розроблено систему управління бізнес-процесом виробництва скляної тари на підприємстві Ілона ЛТД.

4. Створено модель організаційної структури підприємства, яка відображає розподіл роботи по підрозділах і управлінським органам, між якими формуються певні відносини, пов'язані з реалізацією владних повноважень, потоків розпоряджень та інформації.

5. Проведене виділення бізнес-процесів підприємства та створення його процесної моделі, яка описує процес послідовного перетворення матеріальних, сировинних і інформаційних потоків підприємства дозволило визначити процеси для подальшої їх автоматизації.

6. Розроблена BMPN нотація, яка відображує в зручной формі бізнес-процеси, які проходять в компанії, та їх зв’язок, послідовність, відношення до структурних підрозділів дозволила остаточно визначити конкретні процеси для автоматизації.

7. Розроблене та затверджене технічне завдання на створення програмного забезпечення для АСУП, а саме створення програмного продукту зберігання, контролю, обліку і аналізу даних про замовлення, складськи запаси 
сировини, готової продукціі, постачальників та замовників, результатів інвентарізації, розрахунків сировини для виробництва стало основою для розробки програмного продукту - сайту.

8. Створення інтерфейсів та функціоналу для кожного 3 керівників бізнес-процессів, яки були автоматизовані забезпечило зручне використання програмного продукту для користувача.

9. Подальший розвиток питання автоматизації управління процесом виробництва скляної тари знайде в випускній роботі магістра.

\section{Список використаних джерел}

[1]. Офіційний веб-сайт компанії - https://www.oracle.com/ru/erp.

[2]. Офіційний веб-сайт компанії - http://1c.ua/ua/.

[3]. Сайт компаніï - https://odessa.1cbit.ua/bas/erp.

[4]. Офіційний сайт компанії - https://www.wgsoftpro.com/2017/main.php.

[5]. Випускна робота бакалавра «Автоматизація процесу управління виробництвом скляної тари на підприємстві «Ілона ЛТД» [Рукопис] / Аскаров Н.А.- Одеса: Одеська національна академія харчових технологій.- $116 \mathrm{c}$.

\section{References}

[1]. Ofitsiynyy veb-sayt kompaniyi - https://www.oracle.com/ru/erp.

[2]. Ofitsiynyy veb-sayt kompaniyi - http://1c.ua/ua/.

[3]. Sayt kompaniyi - https://odessa.1cbit.ua/bas/erp.

[4]. Ofitsiynyy sayt kompaniyi - https://www.wgsoftpro.com/2017/main.php.

[5]. Vypuskna robota bakalavra Avtomatyzatsiya protsesu upravlinnya vyrobnytstvom sklyanoyi tary na pidpryyemstvi «Ilona LTD» [Rukopys] / Askarov N.A. Odesa: Odes'ka natsional'na akademiya kharchovykh tekhnolohiy. 116 p.

УДК 621.74.041:669.15

\section{НОВЕ СХЕМОТЕХНІЧНЕ РІШЕННЯ ЗУБУ КОВШУ ЗЕМЛЕРІЙНОЇ МАШИНИ ДЛЯ РОБОТИ У ВАЖКИХ УМОВАХ ЕКСПЛУАТАЦЇ̈}

Дрозд О. В.

Національний університет "Одеська морська академія", м. Одеса, Україна

E-mail: elenadrozd912@gmail.com

Copyright (C) 2021 by author and the journal “Automation of technological and business - processes”.

This work is licensed under the Creative Commons Attribution International License (CC BY).

http://creativecommons.org/licanses/by/4.0

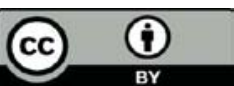

ONAFT

Open Access

DOI:

Анотація. Виробничі ичикли в агропромисловому комплексі часто пов'язані з виробництвом земляних робіт, вартість яких досить велика. Роботи з трунтом найбільш економічні при застосуванні ефективних багатофункиіональних $i$ багаторежимних засобів механізації. Ращіональний вибір методу $i$ засобів механізаціі трунтових робіт, особливо в важких умовах, є необхідною умовою їх успішного виконання. В даний час існує гостра проблема, яка полягає у формуванні парку землерийних машин. Особливу актуальність проблеми додає те, щчо вартість $i$ функціональність машин для земляних робіт зарубіжного виробництва в кілька разів вище, ніж вітчизняних аналогів. Подолати відставання вітчизняних зразків можливо шляхом технічної модернізації як машин в цілому, так $і$ окремих їх елементів. Це може бути досягнуто иляхом розширення технічних можливостей, збільшення потужності силових установок, робочих і транспортних швидкостей, маневреності, тягових зусиль, тисків в гідросистемах, використання швидкодіючих захватів і швидко-діючих з'єднань для швидкої зміни робочих органів. Одним з важливих аспектів модернізації є проектування $і$ виробництво надійних, багатофункціональних робочих органів зі збільшеним ресурсом для землерийних машин, особливо для тих, щчо експлуатуються в важких умовах. Запропоноване схемотехнічне рішення зубу ковшу відрізняється тим, щз корпус-адаптер з внутрішнього боку має гвинтові нарізи та гвинтову пружину, з якою сполучена коронка зі вставками з карбіду вольфраму, яка відповідними виступами на тілі входить у поглиблення гвинтових нарізів корпусу-адаптера та має ущільнювальний елемент між коронкою та корпусом. При контакті з вантажем при завантаженні під тиском ковшу корониі, завдяки контакту виступів на ї̈ тілі та нарізів у корпусі, надається обертальний рух. Це приводить до проникнення 